H. Pylypenko1, Dr. Sc. (Econ.), Prof., orcid.org/0000-0003-2091-4320,

N. Fedorova², Cand. Sc. (Econ.), Assoc. Prof., orcid.org/0000-0003-1693-6260,

I. Huzenko ${ }^{1}$, Cand. Sc. (Econ.), Assoc. Prof., orcid.org/0000-0001-9554-6126,

N. Naumenko ${ }^{2}$, Cand. Sc.(Tech.), Assoc. Prof., orcid.org/0000-0002-0585-932X
1 - Dnipro University of Technology, Dnipro, Ukraine, e-mail: annapylyp@ukr.net

2 - State Higher Education Institution "Ukrainian State University of Chemical Technology", Dnipro, Ukraine, e-mail: sandetskaya777@ukr.net

\title{
PARADOXES OF ECONOMIC DEVELOPMENT: SCIENCE AND INNOVATION IN THE MODERN WORLD
}

Purpose. To determine current tendencies of the effect of science on economic growth of certain countries in the world and to formulate theoretical and methodological approaches to their explanation in the context of social and economic development of the society.

Methodology. The research applies the totality of general scientific and specific methods and approaches of empiric and theoretical knowledge, i.e.: methods of analysis and synthesis - to study sources and tendencies of the modern economic growth; grouping and classification - while forming sampling of the countries to analyze the effect of science on their development; method of mathematical statistics - for quantitative evaluation of the effect of science and innovations on economic growth of certain countries in the world; abstracting - to identify the reasons of inconformity of theoretical conclusions of the economic growth models to the modern tendencies of social and economic growth.

Findings. Effect of the factors connected with the scientific and technical progress on economic growth has been tested empirically. Basing on the Integral Science Index developed by the authors, parameters of the science effect on the economic growth of certain countries in the world have been evaluated quantitatively. Qualitative assessment of the connection between the mentioned Index and GDP per capita in different groups of countries is represented with the help of a sampling coefficient of correlation characterizing the degree of closeness of linear correlation dependence. It has been determined that there is no direct connection between the science and economic growth; the paradox is explained in detail.

Originality. Inconsistencies of the key conclusions of the models of economic growth with current tendencies of social and economic development have been identified. A statement concerning the uniqueness of the effect of science on the development of countries has been disproved. A necessity of going beyond the economic and mathematical set of tools, while studying economic development, in favour of complexity and multidisciplinarity has been proved.

Practical value. The determined variability of the effect of science on the economic growth approves the understanding of ambiguousness and nonlinearity of the process; thus, it requires constant empiric tests of the available dependences and searching for new influences depending on the stage of civilization process which different countries experience. All that helps substantiate the fundamentals of economic policy of national governments in their favouring social and economic development by selecting more effective leverages.

Keywords: science, innovations, economic growth, social and economic development, models of economic growth, Integral Science Index

Introduction. Economic development of the society has many sources; however, there are no contradictions as for the fact that science was the key factor to accelerate social progress in the $20^{\text {th }}$ century. Those were scientific and technical revolutions to be a catalyst for transformation of the technical and technological production basis opening the way to the innovations in all the spheres of social functioning. The innovations have changed radically the natural, economic, social, and sociocultural environment of the human existence having created the unprecedented possibilities for satisfying the needs and progress. However, in this context, one could observe deepening of the economic processes, intensification of their uncertainty and instability along with sharpening of social and economic contradictions. As M. Castels emphasized, new information and communication technologies (being the basis for new sources of productivity, new forms of organization, and development of global economy) favour the economic progress and material welfare since they potentiate power, knowledge, and creative work. Their application still differs with the nonuniformity either within one country or while comparing different countries (Kastels, 2004).

That nonuniformity has become a peculiar puzzle: having transformed from the industrial to post-industrial society owing to the scientific progress, only the USA and the Western European countries have become able to support that progress and provide high rates of social and economic development. As practice shows, other countries were unable to produce new knowledge and technologies constantly; as a result, nowadays,

(C) Pylypenko H., Fedorova N., Huzenko I., Naumenko N., 2020 they still depend on the Western world. Thus, on the one hand, advances of scientific and technical revolutions have favoured the solution of emergent social and economic issues of the world poorest countries; on the other hand, those achievements have widen the gap between the progress level of the developed and developing countries as well as between the countries which have transformed from the administrative system to the market one (countries with transitional economy). Along with that, beginning from the last quarter of the $20^{\text {th }}$ century, we have been witnessing certain paradox in the development of the rich countries which face such new challenges as aging of population, increasing flow of migrants from the poor countries, environmental pollution, and the aggravating inequality. All those contradicting consequences of the science effect are to be expected and taken into consideration while solving the problems of modern social and economic development.

Literature review. Economists got interested in the ambiguous effect of science on the social and economic development of different countries in the world from the moment of the origin of the Solow model of economic growth which forecast inevitable convergence of the countries having access to the same technologies. E. Denison, P. Romer, R. Lucas, P.Aghion, P. Howitt, P. Diamond, O. Galor, D. Weil and some other researchers tried to explain current worldwide divergence of the countries by means of the development of multi-factored models of economic growth which were based on the conditions accelerating scientific and technical progress and innovations (paper [1] gives the detailed description of those models).

Ambiguous consequences of the effect of science on the social life, which were not explained in terms of the economic 
growth theories, favoured gradual expansion of the subject area of studies up to the factors of social and economic development. The latter is based on the economic growth; however, it takes into consideration the effect of social, legal, political, ecological, and culturological factors of the civilization advance of the society. In the context of innovative approaches, W. Northouse related economic growth with the effect of ecological factors having proved that the environmental pollution impacts the quality of human capital and decelerates economic growth $[2,3]$. D. Acemoglu and D. Robinson were the founders of the theories where different rate of economic growth was explained by the quality of institutional environment. The researchers consider political institutions as the most important thing in the economic growth processes [4]. Ch. Jones made an attempt to evaluate statistically the role of social and political factors in the labour productivity increase [5].

Thus, to measure the processes of economic dynamics and evaluate the role of science and technologies in terms of the phenomena arising in the process of social and economic development either at the level of some countries or at the level of the world economy on the whole, different models are being developed and numerous approaches and concepts are being applied. Among them, the following have become the most popular ones: theories of subjective line of political economy, economic theories of pragmatic content with the developed apparatus of mathematical statistics and modelling (neoclassic theories, a set of modifications of the theory of great economic cycles); relatively new theoretical and conceptual statements on the evolutional economy and knowledge-based economy. However, they did not always allow explaining the features and contradictions of modern processes of innovative and technological development: from time to time, numerous empiric facts rejected the conclusions made by the predecessors and forced the successors to make new theoretical and methodological searching.

Purpose of the paper is to determine modern tendencies of the effect of science on the economic growth of certain countries and to formulate theoretical and methodological approaches to their explanation in the context of social and economic development of the society.

Results. First attempts to describe the effect of science on the economic growth were made in the middle of the $20^{\text {th }}$ century when the world witnessed the results of scientific and technical revolution of the 1950-1960s. Publication of the article by R. Solow "Contribution in the theory of economic growth" (Solow, 1956) was the peculiar push for the formation of the idea concerning the effect of a scientific factor on the economic growth rates. Applying the neoclassic prerequisite about mutual replacement of the production factors and their negative payoff, R. Solow modified Cobb-Douglas production function by introducing the exogenous effect of technical progress into the analysis. Despite certain simplification of the production function apparatus for evaluation of the rates of technical progress and its effect on the economic growth dynamics, its application made it possible to make certain conclusions concerning the tendencies and periodization of the processes of the economy intensification. In this context, verification of either simplified (by Cobb-Douglas type) or more complex production functions (e.g. VES functions with certain changes in the replacement elasticity) helped prove ambiguously the importance of the effect of scientific and technological progress (STP) on the economic growth. That was the scientific and technical progress which had to multiply the workforce, transforming it into the constant growing factor. Owing to the technical progress effect, R. Solow explained gradual attenuation of the economic growth rates in the developed countries and their faster dynamics in the developing countries. However, the latter, having low capital-labour ratio and considerable workforce, had a great potential for growing in terms of the increasing reserves of capital facilities (Solow, 1956). According to such logics, all the countries with the access to one and the same technologies had to converge gradu- ally in their development. Such a convergence was observed in terms of some industrially developed countries (that was demonstrated by R. Solow); however, nothing of the kind was found in the countries of Latin America, Africa, and Asia.

Approach by E. Denison (Denison, 1967) was a push to search for the explanation of the contradictions between the results of the Solow model and world tendencies of the economic growth on the basis of the analysis of certain STR factors effect on the total production output. The scientist divided the economic growth factors into two enlarged groups covering labour and capital on the one hand, and technical progress on the other hand. Having compared their influence on the economic growth in terms of the sampling of two European countries and the USA, E. Denison concluded that both Europe and the USA had approximately equal shares of labour and capital within the period of 1950-1962 (78 and $22 \%$ and 82 and $18 \%$ respectively). The thing which differentiated that was the costs for scientific studies in the sphere of technological knowledge and their efficiency. According to the calculations by E. Denison, the USA costs for science were by 4 times higher than the European ones; moreover, the USA employment in the sphere of scientific studies was by 2.2 times higher than that index in Europe. Thus, it became clear that the economic growth is determined not only by the amount of the spent production factors, but rather by the increase in their quality and, first of all, technical innovations and education. E. Denison demonstrated that technical progress ensured about $40-50 \%$ of the USA economic growth and average $2 / 3$ increase in the USA labour productivity during the second half of the $20^{\text {th }}$ century. In its turn, education development within the period of 1929-1959 resulted in $23 \%$ of annual economic growth in that country.

A model by E. Denison as well as the discovery by T.Schultz and G.Becker concerning the human capital (Schultz, 1960; Becker, 1964) encouraged the researchers to pay attention to the factors connected with the effect of the latter on the economic growth. They also played an important role in the 1980s when neoclassic theory was complemented by numerous neofactorial and neotechnological models as for the development of the models of endogenous scientific and technical progress based on the idea of human capital accumulation. In terms of those highly formalized models, the economic growth mechanisms are interpreted as the growing social profit from the investment in the STR and human capital.

Papers by P. Romer and R. Lucas belong to the landmark studies in the framework of new theories of growth ("new wave" theories). They tried to explain current divergence of the countries by the difference in human capital. The scientists relied on the prerequisite that all the economies have similar access to one and the same technologies; nevertheless, they have different level of the investments in human capital. Correspondingly, countries with low level of human capital cannot master the available storage of knowledge, so their being behind the others in terms of technical progress is inevitable.

A model by R. Romer represents the output as the product of the capital stock and productivity; it means that the investments in this model develop new facilities with constant rate. Productivity is dependent on the workers' ability for self-development, their obtaining of new possibilities to master new knowledge and implement new technologies (human capital). Aiming to maximize the profit, each form makes a decision concerning the investment in physical capital and scientific studies taking into account current state of the art in the society. Thus, further decisions as for investing in studies are made with the consideration of the new greater technical possibilities. Consequently, combination of the process of generation of endogenous technical changes with the process of their application in production of benefits results in powerful mechanism of economic growth. According to the calculations by R. Romer, if the available knowledge and current research efforts are doubled, then the result will increase by 4 times; one- 
time increase in the research efforts shows permanent growth of the economic development rate (Romer, 1992).

In terms of the model by R. Romer, production function took into account human capital in the implicit form (it was a factor of the productivity increase); in a model by R. Lucas, developed some time later, the human capital was considered as a separate factor of economic growth. The scientist demonstrated that the growth rate of the human capital itself is directly proportional to the time spent for the learning. Thus, the countries, producing capital-intense (in terms of human capital costs) commodities, intensify their competitive advantages owing to the reduced production costs while implementing high technologies. Correspondingly, they will have more possibilities for their economic growth. Overall conclusion of the model is in the statement that "the economy starting from the low level of physical and human capital will be permanently behind the economy which has better starting conditions in terms of those two capitals" (Lucas, 1988).

Another line of the "new wave" theory was connected with the formalization of the idea by J. Schumpeter concerning structural breaking and detailed development of the structure of origin and implementation of innovations as well as determination of their role in the economic growth. That group of models was called Research \& Development. Development of innovations was singled out theoretically into a separate sector of economy; institutional basis of the functioning of the innovative process and sources for its financing were considered. Among the models of that line, attention should be paid to a model by P. Aghion and P. Howitt where, contrary to the Romar model, innovations not only increase the total level of technologies but also squeeze out previous innovative products making them morally obsolete (Aghion \& Howitt, 1992). So, the innovations, being dependent on the resources aimed at the purpose of research, result in sharp increase of the labour productivity helping support high rates of economic growth. Studies by $\mathrm{Ch}$. Jones concretized that conclusion: if a country increases its resources involved in R\&D, then it favours economic growth (Jones, 1995). That happens due to the fact that the increasing number of researchers results in the growing number of ideas which can be implemented by the companies striving to maximize their profit.

Determination of the influence of competitive environment on the parameters of the economic growth models was one more significant outcome of the studies in this sphere. In terms of the model by Romer, technologies were the temporarily included factors: each company, investing in the innovation, enters the state of temporary monopoly losing this right in the course of time when, due to diffusion, the development becomes a public product in the improvement of technological level of the economy. The same prerequisite formed the basis of the Schumpeterian concepts. In terms of those concepts, growths are determined by the change in the innovation generations owing to the increasing number of the ideas depending on the resources aimed at the studies. Those resources are allocated by the companies-innovators taking into account the innovative rent which they get until new innovation appears making the previous set of benefits obsolete.

Focusing on the explanation of differences in the growth rates and cases of stable considerable growth, the economists tried to connect endogenous technological changes with the international trade and openness. A model of technological expansion developed by R. Barro and H. Sala-i-Martin means that there is a certain transfer of technologies between the countries divided into the countries-technological leaders and countriesfollowers. The latter takes the technological experience of the leaders; in the balanced state, growth rate of their key parameters is equal to the development rates of the leaders. Under such conditions, the authors believe that there will be the conditional convergence (Barro \& Sala-i-Martin, 19991, 1992). R. Barro and $\mathrm{H}$. Sala-i-Martin demonstrate that there is undoubted convergence between certain states in the USA, regions in France and prefectures in Japan similar to that one observed in the
OECD countries. Emphasizing the role of savings for acceleration in the third world, the researchers made some conclusions which contradicted the traditional theory, i. e.:

1. If there are no external economic relations, there are no automatic equalizing of the growth rates between the countries. The growth rates remain the same; they depend on the level of technological accumulation and development in a specific country.

2. There are no tendencies of the convergence of per capita incomes between the rich and poor countries with the similar standards of domestic savings.

3. Temporary and long-term growth deceleration in a country results in its chronicle and aggravating staying behind the rich countries.

4. There is constant transfer of the capital from the backward countries to the developed countries, which deepens the gap between them.

Thus, new models have made it possible to formalize the connection (being understandable intuitively and accepted easily at the conceptual level) between the economic growth mechanisms and processes of getting and accumulating new knowledge, which materializes later in the technical innovations. Along with that, they have led their authors to a series of far-reaching assumptions concerning the reasons of current differences in the economic growth rates in certain countries, efficiency of different measures of state scientific-technical and industrial policy, and effect of the processes of international integration and trade on the economic growth rates.

In the beginning of the 1990s, those hypothesis of not only theoretical but also purely practical character stimulated massive scientific discussion, during which some weak points of the new approach to the theory of economic development were identified. R. Solow may be singled out among its first critic; he indicated the fact that many new models used a great number of special and not always sufficiently substantiated and checked assumptions on the character of the modelled technological processes, nature of scientific activity, formation and use of human capital, structure of markets, temporary advantages and others. Their use may be justified only to the extent to which they simplify the description of complex economic phenomena. Along with that, they require constant empiric confirmation and test of a set of hypotheses and conclusions (Solow, 2000).

Current conditions of the development are not the exception here. Basing on the results obtained in the sphere of the research of economic growth, we have the identified regularity as for the following: the countries' welfare depends on the scientific and technical progress, where quality of human capital, volume of the resources for the research and development sector, and motivation of the companies for their innovative activities are the key factors for the acceleration. To define current tendencies of the effect of those factors on the economic growth, we propose to elaborate a special indicator reflecting their interaction with the GDP level as the welfare index of a certain country. The indicator will be called "Integral Science Index", which combines the following constituent parts:

1. Costs for R\&D expressed as percentage to the GDP expressing the development of resource possibilities to produce new knowledge [6].

2. Employment in the knowledge-intense activities - an index acting as a component of the NRI index and characterizing a share of employees involved in the research activity which requires certain level of human capital and, simultaneously, reflects potential possibility of the increase in the number of ideas [7].

3. Quality of scientific and research institutions as a component of the GCI index, assessing efficiency of scientific and research establishments as the source of new knowledge and information [8].

4. Index of cooperation between a university and an industrial company as the component of GCI characterizing the fact to what extent business and universities cooperate in the sphere of research and development. It shows the degree of 
relations between theoretical and applied knowledge being the evidence of companies' interest in the innovations [8].

5. Application for patents - an index belonging to the group of global indices NRI and GCI; it reflects the results of scientific activities in the form of patents for inventions, it may be considered as a peculiar barrier for the companies-imitators [8].

6. Scientific and technical publications - an index being a component of GII; it shows the results of scientific activities in the form of discoveries and inventions being given to the public and may be the basis for their practical use [6].

7. Hirsch index as the component of GII; it expresses the number of published articles having $\mathrm{H}$-citation. It characterizes the efficiency of scientific search and demand on the scientific discoveries, which may be the characteristic of the degree of dissemination of new knowledge [6].

Empiric test of the effect of science on the economic growth with the help of the Integral Science Index is performed in terms of the sampling formed of five types of countries depending on the main resources they use as the source of economic growth. Corresponding classification is as follows:

1. Group of Seven: Germany. Japan, the USA, Great Britain, France, Canada, and Italy. Those are the highly developed countries with post-industrial economy where human capital is the key resource of the economic growth. Scientific and technical interaction, economic integration, and cooperation are of great importance.

2. Asian countries - China, India, and Malaysia. Those are agrarian and industrial countries developing the policy of own economic growth in terms of enclavic use of high technologies mostly on the basis of the developments borrowed from the highly developed countries.
3. Asian "tigers": Singapore, South Korea, and HongKong. Those are new industrial Asian countries which demonstrate significant rates of economic growth; currently, they are focused on active development of the knowledge-intense industries and high technologies.

4. Countries-oil exporters: the UAE, Saudi Arabia, Qatar, and Kuwait. Those are energy superstates where raw material resources are the main source of the economic growth. At the same time, under modern conditions they demonstrate tendencies for the development of knowledge-intense industries.

5. Post-Soviet countries - Ukraine, the Russian Federation, Latvia, and Kazakhstan. The economy of those countries is based on joint scientific basis of the former USSR with its potential military and industrial complex, space industry, and numerous research institutions.

Quantitative indices forming integral science index for the mentioned countries cover the period from 2012 to 2019; they are based on the data by the world organizations, which calculate them. The proposed indices have different measuring units; thus, to analyse and aggregate them, they were subject to normalization. After that, the data characterizing the components of the Integral Science Index were grouped into five specified types of countries.

Table shows the results of the calculation of pair correlation coefficients between the Integral Science Index and GDP per capita as the key indicator of the economic growth in different types of countries as well as in terms of the sampling on the whole. The table gives two data type for each subindex: 1 - value of the correlation coefficient; 2 - calculated value of Student criterion.

The data of Table show that there is no close connection between the Integral Science Index and GDP per capita - generally, in terms of the sampling, coefficient of correlation be-

Correlation of Integral Science Index and GDP per capita components (good $(0.7-0.8)$ and strong $(0.8-1)$ correlations are highlighted in bold; negative correlations are highlighted)

\begin{tabular}{|c|c|c|c|c|c|c|c|c|c|c|}
\hline \multirow[b]{2}{*}{ Indicator } & \multirow[b]{2}{*}{ 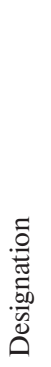 } & \multirow[b]{2}{*}{ 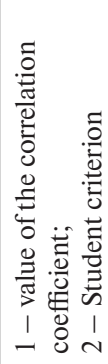 } & \multicolumn{7}{|c|}{ Components of the Integral Science Index, normalized indicators (hours) } & \multirow[b]{2}{*}{ 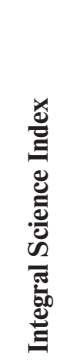 } \\
\hline & & & 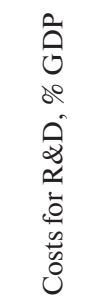 & 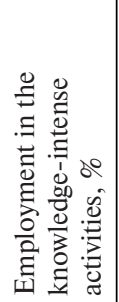 & 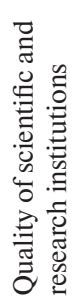 & 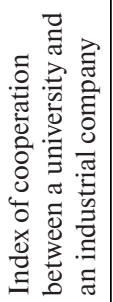 & 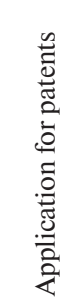 & 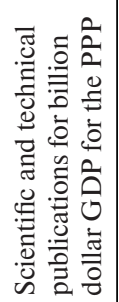 & 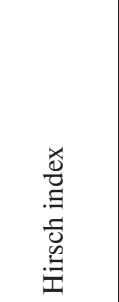 & \\
\hline \multicolumn{11}{|c|}{ Group of Seven } \\
\hline \multirow[t]{2}{*}{ GDP per capita, thousand PPP \$ } & \multirow[t]{2}{*}{$x_{1}$} & 1 & 0.106 & -0.199 & 0.429 & 0.390 & -0.04 & -0.333 & 0.148 & 0.127 \\
\hline & & 2 & 0.488 & -0.931 & 2.175 & 1.942 & -0.16 & -1.617 & 0.686 & 0.585 \\
\hline \multicolumn{11}{|c|}{ Asian countries } \\
\hline \multirow[t]{2}{*}{ GDP per capita, thousand PPP \$ } & \multirow[t]{2}{*}{$x_{1}$} & 1 & 0.477 & 0.655 & 0.547 & 0.723 & 0.634 & 0.568 & -0.382 & 0.904 \\
\hline & & 2 & 1.628 & 2.598 & 1.961 & 3.141 & 2.457 & 2.071 & -1.241 & 6.356 \\
\hline \multicolumn{11}{|c|}{ Asian "tigers" } \\
\hline \multirow[t]{2}{*}{ GDP per capita, thousand PPP \$ } & \multirow[t]{2}{*}{$x_{1}$} & 1 & 0.222 & 0.345 & 0.407 & 0.248 & 0.341 & 0.327 & 0.692 & 0.401 \\
\hline & & 2 & 0.788 & 1.274 & 1.543 & 0.886 & 1.256 & 1.199 & 3.318 & 1.517 \\
\hline \multicolumn{11}{|c|}{ Countries-oil exporters } \\
\hline \multirow[t]{2}{*}{ GDP per capita, thousand PPP \$ } & \multirow[t]{2}{*}{$x_{1}$} & 1 & 0.439 & -0.116 & 0.754 & 0.670 & 0.468 & -0.158 & -0.837 & 0.586 \\
\hline & & 2 & 1.693 & -0.404 & 3.976 & 3.130 & 1.836 & -0.553 & -5.308 & 2.502 \\
\hline \multicolumn{11}{|c|}{ Post-Soviet countries } \\
\hline \multirow[t]{2}{*}{ GDP per capita, thousand PPP \$ } & \multirow[t]{2}{*}{$x_{1}$} & 1 & -0.098 & 0.474 & 0.161 & -0.122 & 0.313 & -0.029 & -0.041 & 0.082 \\
\hline & & 2 & -0.342 & 1.866 & 0.565 & -0.425 & 1.142 & -0.102 & -0.143 & 0.286 \\
\hline \multicolumn{11}{|c|}{ All countries together } \\
\hline \multirow[t]{2}{*}{ GDP per capita, thousand PPP \$ } & \multirow[t]{2}{*}{$x_{1}$} & 1 & 0.301 & 0.294 & 0.613 & 0.518 & 0.395 & 0.291 & 0.345 & 0.489 \\
\hline & & 2 & 2.560 & 2.498 & 6.295 & 4.922 & 3.489 & 2.475 & 2.991 & 4.555 \\
\hline
\end{tabular}


tween them is 0.489. Apart from the Asian countries, where a value of the coefficient of correlation is 0.904 , none of the countries from the analysed group demonstrated distinct effect of science on the social welfare. Those results, being paradoxical at first, are one more empiric confirmation of the aforementioned R. Solow's warning as for the impossibility to model a process of economic growth once and for all. The identified inconsistencies of the dependences formed in the framework of neoclassic models and concepts of economic growth and empirically determined tendencies of the social and economic systems are explained by the manysidedness of the economic processes and their multifactor nature. In its turn, that helps describe them even in terms of the newest economic and mathematical methods; that requires complex studies as well.

Actually, during different periods and in different countries, irrespective of the available dependence between the science financing and GDP, growing costs for R\&D did not always cause the immediate economic growth. The question is about the transfer of the creative impulse from the sphere of science to the sphere of economy. It is interesting that the impulse could either extinct, dissipate or be absorbed, or push the economy for its growth. Situation of the inconsistencies between the R\&D costs and economic growth, when the R\&D costs do not result in the economic growth, looks both completely paradoxical and quite possible. In our opinion, that situation has three main groups of explanations:

1. Economic explanations. Sphere of R\&D relations and sphere of economy, like each of them separately, is subject to the tendency ("law") of diminishing return. Thus, increase in the $R \& D$ costs both in terms of the unchangeable characteristics of human capital, or its deterioration, and in terms of the unchangeable motivation incentives to implement innovations, or their weakening, can result gradually in the decreased revenues and decelerated economic growth. Correspondingly, increasing $R \& D$ costs should be accompanied by the improvement of human capital and intensification of incentives and encouragement of the interest to implement innovations (models by Romer, Lucas, Aghion, Howitt). That requires corresponding governmental influence and institutional environment favourable for the innovations. During the social and economic development of countries, the latter ones experience certain changes and advance new demands for the provision of economic growth at new stage.

It is true that beginning from the 1960-1970ss, the developed countries started investing actively considerable funds in education, health protection, information and telecommunication technologies, which gradually became the basis for new sources of labour productivity, new organizational production forms, and, as a result, formation of the knowledge economy. Those processes favoured the transfer of the developed countries to the domination of the tertiary sector of economy; that made it possible to characterize them as the countries having transferred to the post-industrial society. In this context, R\&D products servicing, IT services, business and professional services in the sphere of managerial consulting, accounting, law, marketing, information and communication, consulting, finances, cultural and recreational services have become the ones to be dominating among all other services.

Being knowledge-intense in their nature, nevertheless, they are not affected considerably by the science as they are not based on revolutionary inventions; they are the result of the improving innovations. Such innovations are aimed at partial improvement of the want-satisfying qualities of goods, parameters of the application of the available technologies; consequently, they are the basis for minor improvements, rationalization and modernization of the products and technologies being used.

Development of the modern service industry in the developed countries is characterized by the use of such technologies which, on the one hand, support new models or modified technologies but, on the other hand, they are developed in terms of the existing generation of technology to expand the market niche and satisfy more differentiated consumer needs. These are the reasons why significant effect of science on the GDP is not felt in the developed countries nowadays. Moreover, investment in fundamental science (being a key feature of the progress model of the developed countries) has no direct connection with current economic growth. New knowledge demonstrates the effect only in the future and exclusively under conditions of the interest in their implementation. That requires creation of additional conditions. Consequently, the countries investing in fundamental science do not accelerate the rates of economic growth at the expense of that factor during a short-term period. However, in the longer term, they become technological leaders. Thus, to provide high rates of economic growth, a country should transfer from the implementation-oriented innovative macro-policy to the institutions of growth which intensify the fundamental innovations. The confirmation here is the transfer of the USA innovative system at the beginning of the $21^{\text {st }}$ century to a new model of "triple spiral" (Etzkowitz, Leydesdorff, 1995). Differing from other models both with its structure and the mechanism of component interaction, it represents the connection between three key institutions of a newly industrialized country - state, business, and science - at all stages from the development to implementation of a new product. Universities are the catalysts of the "spiral" process; augmenting the commercialization of their achievements, the universities become a key for future development, job creation, and economic growth (Etzkowitz, 2008).

In the context of the same diminishing return, it should be remembered that there is no immediate dependence between the investment in R\&D and return from it. The latter may either grow multiply at a growing rate or decrease gradually due to the effect of certain factors, most of which have competitive nature. Increase in the R\&D costs does not result in the corresponding (proportional) economic growth. Moreover, the situation is quite possible when further rising $R \& D$ costs do not result in the proportional growth of the return from the implementation of some innovation and further augmentation of the economic growth rates. Besides, the following factors may also prevent the economic growth owing to the growing costs for R\&D: competition, which not only encourages but holds and decelerates innovation processes; market environment, which may reduce the demand for certain high-technology products; amortization or the need to compensate costs for the development and implementation of the technology of previous innovation wave; complexity, when innovative and technological impulses, sent to a complex and high-technology economies, do not result in those obvious and immediate outcomes, which the innovative and technological impulses, sent to less complex and developed economies, result in.

The latter statement explains great importance of science for current economic growth of Asian countries which base their export-oriented production on the innovative-imitational model of technological development (according to our calculations, coefficient of correlation between the employment in the knowledge-intense activities and cooperation between a university and a production company are 0.655 and 0.904 , respectively). Once, that was the way for the post-war Europe; however, until the mid-1980s, it exhausted completely its possibilities of the overtaking development and had to transfer to the institutions of growth, intensifying the fundamental innovations.

2. Scientific explanations. The sphere of scientific achievements is a separate domain, whose logics of existence cannot be interpreted only in the terms of economic rationality. Much in this sphere depends on creative work, occasion, inspiration, interpersonal relations, and other factors which are slightly subject to any rational interpretation. K. Popper claimed that it is hard to explain rationally the process of invention and discovery; instead, processes of their substantiation, verification, and implementation are of rational character. Moreover, even multiple increases in the costs for the scientific research sphere do not obligatory and always result in great discoveries and in- 
ventions with further economic effect. That sphere also experiences periods of stagnations which, by the way, are not rare. In particular, such periods may be connected with the changes in scientific paradigms (according to T. Kuhn) or research programmes (according to I. Lakatos), in which historical and time frames (paradigms and programmes) inventions and discoveries are made, verified, and implemented. It is obvious that each of those paradigms and programmes generate its own corresponding technologies and technological matrices.

Exhaustion of the scientific paradigms and programmes, first of all on the eve of their changes, results in the corresponding exhaustion of the technological potential of those paradigms and programmes - ability to generate new and productive technological systems (innovations). These are changes in scientific paradigms which are the scientific revolution - radical historic change in the scientific activity and scientific organization. Undoubtedly, a scientific revolution includes a technological revolution as well - creatively destructive flow of innovations causing imminent economic growth. However, time should pass so that the revolutionary changes in scientific thinking and organization would result in the corresponding changes in technological patterns. That is the transition time when considerable R\&D costs have no corresponding effect on the economic growth. Finally, the moment of structural consistency (homology) of science and economy should be focused on. Both scientific and economic domains are structured and function according to certain paradigms which may not only differ but contradict each other. Thus, progressive ideas and theories, quite often formulated and grown in the sphere of science, are able to be a factor of drastic social transformations.

Logic of the research activity and logic of economic activity differ greatly. The similar difference is between the structures and principles of functioning of the domains of science and economy. Generally, the first domain is close to the sphere of culture not less than the sphere of economy, and its certain achievements are "priceless" in all the negative and positive meanings, i.e. either economically priceless or of no economic value for at least some historic moment. Difference between the spheres of science and economy also means that cycles of their functioning (scientific and economic cyclic dynamics) do not always coincide. In particular, periods of scientific rise may coincide with the periods of economic falls when rising dynamics of the scientific development is synchronous to the falling dynamics of the economic progress. At the same time, such asymmetry of the phases of cyclic dynamics of science and economy has certain sense since that is the rise in scientific and research sphere which may further generate a technological impulse for the economic growth or even become the main reason of that growth. Finally, one of the explanation of non-available immediate correlation between the R\&D costs increase and economic growth is the peculiarities of the organization of the science itself. That organization may lose the research productivity, organizational efficiency, and connection with the economy.

Economy of the post-Soviet countries is a prime example here. Those economies are characterized by a paradoxical tendency: intense development of the fundamental science and almost complete absence of the implementation of its results in production. Rich mineral base made it possible for the Soviet Union to support high rates of economic growth without concentration of its efforts on innovation up to the 1990s. Such situation changed dramatically when the developed countries transferred to a new development model and the situation on the world markets changed as well. Increasing demand for the knowledge-intense products deteriorated economic situation in the post-Soviet countries with the following dramatic fall of the economic growth rates. Irrespective of the fact that the reality raised a question about searching for a new model of science-production interaction, it has not been formed yet in those countries.

3. Social uneconomic explanations. Generally, innovative processes may be decelerated by the factors being beyond the economy limits. That is about factors of political, cultural, and legal character. Policy may prevent completely the innovative processes even under conditions of the growing R\&D costs. In particular, we mean elitaristic, conservative, dependent (comparadoristic) political regimes, both authoritarian and democratic based on monopolism and intense social stratification the regimes are static (even crusty), polarized, dependent on the external forces. It is no doubt that the ruling establishment of those regimes is hardly interested in the favouring of economic growth through the development of innovative processes since such an economic policy will undermine inevitably their social basis, forming mighty middle class. There are also cultural factors keeping down the economic growth even in terms of the growing R\&D costs. Particularly, we mean archaic, religious, traditionalistic sociocultural types which are hostile for everything new, i.e. the advent of new technological patterns able to ruin old and traditional lifestyle; hostile for inventions and creative searches; hostile for open and critical mindsets, pluralism, and reasonable scepticism [9]. Such political regimes and cultural types are most of all afraid of the Schumpeterian creative destruction. Finally, imperfect normative base, i.e. in the sphere of protection of intellectual property, may prevent from the economic growth due to the growing $R \& D$ costs.

Conclusions. The research has demonstrated that nowadays, models of economic growth are the most popular tool to analyse a problem related to the economic growth of countries as well as the development of lines of their innovative policy. In terms of the growth theory (like in macroeconomics and economic theory in general), studies are either closely related to the empiric developments being tested and confirmed by them, or subject to doubts and disproval; and, quite often, they are even initiated by the empiric studies.

Having expanded a circle of the analysed countries and periods of time, empirics of economic growth has identified considerable disagreements in the basic statements of the models of economic growth with the reality. Current economic growth may be explained not so much by a system of factors introduced in a model as the fact that is called "Solow's residual", i. e. what is behind it. There are many hidden factors and determinants of that kind; their list has not been determined and completed yet. Moreover, human progress to the new technological life patterns and paradigms will open constantly new sources for economic growth and generate new influences.

Correspondingly, all the theoretical dependences formulated for a specific moment are to be subject to constant empiric test; and methodological arsenal of scientific search has to be changed from time to time to meet the realias. If we want to know more about the laws and tendencies of economic growth and to control efficiently that processes, we should take into consideration the factors which are appropriate for all the social spheres but not only for the economy. That makes us carry out scientific research in the sphere of problems not dealing with the growth but dealing with the social-economic development, applying the methodology based on the achievements of modern social science.

\section{References.}

1. Zamulin, O., \& Sonin, K. (2019). Economic Growth: 2018 Nobel Prize and Lessons for Russia. Voprosy ekonomyky, 1, 11-36. 2. Nordhaus, W. (2017). Integrated assessment models of climate change. NBER Reporter, 3, 10-20.

3. Nordhaus, W., \& Moffat, A. (2017). A survey of global impacts of climate change: Replication, survey methods, and a statistical analysis. NBER Working Paper, 23646, 1-39. https:// doi.org/10.3386/w23646.

4. Acemoglu, D., \& Robinson, J. (2019). Rents and Economic Development: the perspective of why nations fail. Public Choice, 118, 13-28. https://doi.org/10.1007/s11127-019-00645-z.

5. Jones, Ch. (2016). The facts of economic growth. In: J. Taylor, \& H. Uhlig (Eds.). Handbook of macroeconomics (Vol. 2, pp. 3-69). Amsterdam: Elsevier.

6. The Global Innovation Index 2019. Retrieved from: https:// www.globalinnovationindex.org//gii-2019-report. 
7. The Networked Readiness Index 2019. Retrieved from: https://widgets.weforum.org/.

8. The Global Competitiveness Report 2019. Retrieved from: https://www.weforum.org/.

9. Pylypenko, H., Lytvynenko, N., \& Barna, T. (2019). Sociocultural context of innovative development. Philosophy and Cosmology, 23, 98-111. https://doi.org/10.29202/phil-cosm/23/9.

\section{Парадокси соціально-економічного розвитку: наука та інновації в сучасному світі}

\author{
Г. М. Пилипенко , Н. С. Федорова ${ }^{2}$, І. Ю. Гузенко ${ }^{1}$, \\ Н. Ю. Науменко ${ }^{2}$
}

1 - Національний технічний університет «Дніпровська політехніка», м. Дніпро, Україна, e-mail: annapylyp@ukr.net 2 - Державний вищий навчальний заклад «Український державний хіміко-технологічний університет», м. Дніпро, Україна, e-mail: sandetskaya777@ukr.net

Мета. Встановлення сучасних тенденцій впливу науки на економічне зростання окремих країн світу та формування теоретико-методологічних підходів до їх пояснення в контексті соціально-економічного розвитку суспільства.

Методика. У дослідженні застосовано сукупність загальнонаукових та специфічних методів і підходів емпіричного й теоретичного пізнання, зокрема: методи аналізу й синтезу - для визначення джерел і тенденцій сучасного економічного зростання; групування й класифікацій - при формуванні вибірки країн задля дослідження впливу науки на їхній розвиток; методи математичної статистики - для кількісної оцінки впливу науки та інновацій на економічне зростання окремих країн світу; абстрагування - для встановлення причин невідповідності теоретичних висновків моделей економічного зростання сучасним тенденціям соціально-економічного розвитку.

Результати. Здійснена емпірична перевірка впливовості на економічне зростання факторів, пов'язаних із науково-технічним прогресом. На основі розробленого авторами показника - інтегрального індексу науки, кількісно оцінені параметри впливу науки на економічне зростання окремих країн світу. За допомогою вибіркового коефіцієнту кореляції, що характеризує ступінь щільності лінійної кореляційної залежності, надана кількісна оцінка зв'язку між указаним індексом і ВВП на душу населення в різних групах країн. Встановлена відсутність прямого зв'язку між наукою та економічним зростанням і надане пояснення даному парадоксу.

Наукова новизна. Встановлена невідповідність ключових висновків моделей економічного зростання сучасним тенденціям соціально-економічного розвитку. Спростоване твердження щодо універсальності наслідків впливу науки на розвиток країн. Доведена необхідність виходу за межі економіко-математичного інструментарію в дослідженні економічного розвитку на користь комплексності та мультидисциплінарності.

Практична значимість. Встановлена варіативність впливу науки на економічне зростання утверджує розуміння неоднозначності й нелінійності даного процесу, а значить, вимагає постійних емпіричних перевірок існуючих залежностей та пошуку нових факторів впливу залежно від стадії цивілізаційного руху, на якій перебувають різні країни світу. Усе це дозволяє обгрунтувати засади економічної політики національних урядів у сприянні соціально-економічному розвитку через вибір більш дієвих інструментів впливу.

Ключові слова: наука, інновації, економічне зростання, соціально-економічний розвиток, моделі економічного зростання, інтегральний індекс науки

\section{Парадоксы экономического развития: наука и инновации в современном мире}

\author{
А. Н. Пилипенко ${ }^{1}$, Н.Е. Федорова ${ }^{2}$, И. Ю. Гузенко ${ }^{1}$, \\ Н. Ю. Науменко ${ }^{2}$
}

1 - Национальный технический университет «Днепровская политехника», г. Днепр, Украина, e-mail: annapylyp@ ukr.net

2 - Государственное высшее учебное заведение «Украинский государственный химико-технологический университет», г. Днепр, Украина, e-mail: sandetskaya777@ukr.net

Цель. Выяснение современных тенденций влияния науки на экономический рост отдельных стран мира и формирование теоретико-методологических подходов к их объяснению в контексте социально-экономического развития общества.

Методика. В исследовании применена совокупность общенаучных и специфических методов и подходов эмпирического и теоретического познания, в частности: методы анализа и синтеза - для определения источников и тенденций современного экономического роста; группировки и классификаций - при формировании выборки стран для исследования влияния науки на их развитие; методы математической статистики - для количественной оценки влияния науки и инноваций на экономический рост отдельных стран мира; абстрагирование для установления причин несоответствия теоретических выводов моделей экономического роста современным тенденциям социально-экономического развития.

Результаты. Осуществлена эмпирическая проверка влияния на экономический рост факторов, связанных с научно-техническим прогрессом. На основе разработанного авторами показателя - интегрального индекса науки, количественно оценены параметры влияния науки на экономический рост отдельных стран мира. С помощью выборочного коэффициента корреляции, характеризующего степень плотности линейной корреляционной зависимости, представлена количественная оценка связи между указанным индексом и ВВП на душу населения в различных группах стран. Установлено отсутствие прямой связи между наукой и экономическим ростом и предоставлено объяснение данного парадокса.

Научная новизна. Установлено несоответствие ключевых выводов моделей экономического роста современным тенденциям социально-экономического развития. Опровергнуто утверждение об универсальности последствий влияния науки на развитие стран. Доказана необходимость выхода за пределы экономико-математического инструментария в исследовании экономического развития в пользу комплексности и мультидисциплинарности.

Практическая значимость. Установленная вариативность воздействия науки на экономический рост утверждает понимание неоднозначности и нелинейности данного процесса, а значит, требует постоянных эмпирических проверок существующих зависимостей и поиска новых факторов влияния в зависимости от стадии цивилизационного движения, на которой находятся различные страны мира. Все это позволяет обосновать принципы экономической политики национальных правительств в содействии социально-экономическому развитию через выбор наиболее эффективных инструментов влияния.

Ключевые слова: наука, инновации, экономический рост, социально-экономическое развитие, модели экономического роста, интегральный индекс науки

Recommended for publication by O.V.Tryfonova, Doctor of Economic Sciences. The manuscript was submitted 13.04.19. 